Canadian Journal of Family and Youth, 8(1), 2016, pp 73-101

ISSN 1718-9748 (C) University of Alberta

http://ejournals.library.ualberta.ca/index/php/cjfy

\title{
"Other" Characters: The Gendering and Racialization of "Disability" Within Newbery Award-Winning Books, 1922-2012
}

\author{
Adie Nelson \& Veronica (Ronnie) Nelson
}

\begin{abstract}
Disability rights activists have long urged recognition of the import of cultural representations and their salience in the Othering process. Previous research on children's picture books and novels has noted that persons with disabilities are commonly depicted in stereotypic and dehumanizing ways. This article explores the extent to which stereotypes of disability may be gendered and/or racialized by examining children's books that won the American Library Association's Newbery Medal between 1922-2012. It notes that the crafting of female and male characters with disabilities within these books pays homage to traditional gender roles, images and symbols and, most notably, reiterates an active-masculine/passive-feminine dichotomization. In addition, these representations suggest how racial essentialism is implicated in the production of "disability" within children's literature, with non-white "racial" identity equated with various forms of impairment.
\end{abstract}

\footnotetext{
Adie Nelson is an Associate Professor at the University of Waterloo in the Department of Sociology and Legal Studies. She obtained her PhD in 1983 from the London School of Economics and is the author/co-author/co-editor of over two dozen books. Her primary areas of research are victimology, criminology and the sociology of the family. Her most recent scholarly articles include "'Heroes' and victims: Incarcerated bank robbers' accounts of victims and victimization" (with F.J. Desroches), International Review of Victimology 20(2): 211-226, 2014; "Framing the picture: The Canadian print media's construction of an atypical crime and its victims" International Review of Victimology 19(3) September: 285-305, 2013 (with J.P. Nelson) and (with J.P. Nelson) "The crime that pays? Constructing art fraud." The Journal of Art Crime 10 fall: 3-18, 2013. Veronica (Ronnie) Nelson is a JD candidate at the University of Ottawa Law School. Her primary areas of research are cyberbullying and social exclusion. Her publications include "Hey Mitch-elle, you need a shave!" The school days of hirsute adolescents." Qualitative Sociology Review 6(2): 99-114, 2010 (with Adie Nelson) and "Reconceptualizing dreamwork (with apologies to Lewis Carroll's Alice) as a facet of motherwork." Qualitative Sociology Review 6(3): 73-88, 2010.
} 
Nelson and Nelson

\section{Introduction}

Disability rights activists have long urged recognition of the import of cultural representations as "constitutive as well as reflective ways of seeing, thinking and talking about disability" (Sandell \& Dodd, 2010, p. 3). In taking up this challenge, Biklen and Bogdan (1977) identified ten stereotypical ways in which persons with disabilities were represented by the media: as "pitiable and pathetic"; "object of violence"; "object of ridicule"; "sinister and evil"; "atmosphere or curio"; "super cripple"; "their own worst enemy"; "a burden"; "asexual”or sexually abnormal; and "incapable of participating fully in everyday life." Analyses of both picture books and novels for very young children (e.g., Beckett et al., 2010; Dyches \& Prater, 2005) have suggested the tenacity of these "disabling images" (Gartner \& Joe, 1987, p. 2). This article explores the extent to which stereotypes of disability may be gendered and/or racialized by examining works that are aimed at a slightly older audience and, between 1922-2012, were the recipients of the American Library Association's Newbery Medal.

The Newbery Medal, which is "awarded annually to the author of the most distinguished contribution to American literature for children published by an American publisher in the United States in English during the preceding year" (American Library Association, 2014), has been described as the preeminent award for children's literature (Kidd, 2007, p.166). It has been lauded as "the giant among children's book awards" and hailed as capable of conferring a type of marketplace-based immortality upon the works that it honours, inasmuch as winning the award purportedly "guarantees that a title is kept in print in perpetuity" (Lowe, 2004, p. 6). Given this enviable stature it is not, perhaps, surprising that the content of these books, which target children fourteen years of age and under (American Library Association, 2012) have been subject to frequent scrutiny. For example, Cook's (1985, p. 428) qualitative content analysis of the 1941 to 1981 award winners observes that these books present a worldview that is largely 
rural, middle-class and white, with the working class both underrepresented and most susceptible to negative portrayal. His examination of the Newbery medal winners as vehicles of political education and cultural reproduction also found that the theme of individual self-reliance and efficacy has been continuously touted despite shifts in the preferred genre from "fantasy and legends in the twenties through historical fiction and biography in the thirties and forties to contemporary realistic fiction, first set in other lands in the fifties, and nowadays set in the United States" (Cook, 1985, p. 421). While other scholars have scrutinized subsets of Newberymedal winning books for the images that they convey of, for example, "race"/ethnicity (e.g., Lopez-Crowley, 2007), social class (e.g., Wollenziehn, 1996), and gender (e.g., Boster, 2005; Lathey, 2008), our search of the $P D Q T$ datebase, which employed "Newbery Award" in combination with "disability" without date range specifications, yielded a single article.

Inasmuch as Leininger et al. (2010: p. 583) sought "to determine the number of Newbery Medal and [runner-up] Honor Books from 1975-2009 "that include prominent characters with disabilities and analyse how these characters are portrayed" following the 1975 passage of the Individuals with Disabilities Act (IDEA) in 1975 and its 1990 reauthorization, it is not, perhaps, surprising that they operationalized "disability" to conform to the dicta of the IDEA. Thus, they note that their research only included books in which "at least one main (protagonist or antagonist) or supporting character had a disability of a degree that would warrant special education and/or related services in school settings, even if the setting for the book was not in school or if the character was an adult" (Leininger et al., 2010, p. 584, emphasis added). Moreover, they specify that while they only included "characters with orthopedic impairments... if their disability was deemed significant enough to warrant physical or occupational therapy services," "[c]haracters with illness-related impairments were not evaluated if the character's disability appeared to not affect his/her educational performance (e.g., 
cancer)." Based upon these criteria, they report that 31 of the 131 books possessed "at least one main (protagonist or antagonist) or supporting character" with a disability, with Honor books more likely to do so than award-winners. Their research additionally finds that the representation of Newbery characters with disabilities was not proportionate with the current U.S. population of students with disabilities and that while the gender distribution of characters was a "fairly accurate representation" of students who receive special education services," the racial composition of these characters was not representative of American students, with whites overrepresented, Blacks and Hispanics underrepresented and Indian/Alaskan Natives most conspicuous by their absence (Leininger et al., 2010, p. 583). Their evaluation of these books, which was based upon an adaptation of the Rating Scale for Quality Characterizations of Individuals with Disabilities in Children's Literature (Dyches \& Prater, 2000), concludes that the "personal portrayal, exemplary practices, social interactions, and sibling relationships associated with characters with disabilities in Newbery books were generally positive and have improved over time." Nevertheless, they note, albeit in fleeting fashion, that "certain concerning themes were identified, such as the elimination of the character with the disability or miraculous cures" and that characters with disabilities were generally cast in supporting rather than focal roles (Leininger et al., 2010, p. 594).

While Leininger et al. (2010, p. 583) acknowledge that "it is possible" that they failed to identify all of the main or supporting characters with disabilities that appeared within the books they examined and that there may have been bias "in the determination of which characters with disabilities were eligible for evaluation," they suggest that these potential limitations were largely redressed through "consulting the IDEA definitions of each disability as well as consulting with knowledgeable professionals in the field of special education." Yet, despite these precautions, their list of "characters with disabilities" (Leininger et al., 2010, p. 585) would seem 
incomplete in light of their announced criteria. For example, it notably omits the focal character of "Lynn" within Kira Kira, the 2005 Newbery medal winner, even though Kadohata's (2004) novel portrays this young Japanese-American female as dying from cancer and repeatedly ailing and/or hospitalized - events that would have, presumably, impacted her "educational performance." Among other characters excluded from Leininger et al's list are: an AfricanAmerican male whose face is horrifically burnt as the result of a racist attack in which he is doused in kerosene and set ablaze (i.e., "Mr. Berry" in Taylor's [1977] Roll of Thunder, Hear My Cry); the "retarded” Rosalie Bumbach in Raskin's (1978) The Westing Game; the "blind” Mrs. Partridge in Creech's (1994) Walk Two Moons; a young man who experiences multiple impairments after being "gassed in the trenches" (the unnamed son of "Mrs. Abernathy" in Peck's [2000] A Year Down Yonder); and a second unnamed young man who is depicted as a double amputee and portrayed in a full-page illustration in the 2006 winner, Criss Cross (Perkins, 2005). In like fashion, it is unclear why Leininger et al.'s (2010, p. 585) list would include the character of "Uncle Ob" - who is described in the 1994 Newbery Medal-winning novel Missing May as “an old arthritic skeleton of a man” (Rylant, 1993, pp. 86-87) - but exclude his wife, the book's titular character, “Aunt May,” who dies from a lethal combination of diabetes and extreme obesity.

On the assumption that authors do not use words artlessly nor introduce characters into their stories that they consider to be wholly superfluous to its plot, it would seem at least arguable that all of these corporeally distinctive characters, along with others, merit inclusion in a study that seeks to investigate how disability in represented within Newbery Award winning books. While it is true that some of these characters were "background" characters who appeared only briefly and/or went unnamed, literature assuredly possesses the "capacity to charge relatively limited quantities of information with a sense of significance and to consolidate them 
Nelson and Nelson

into patterns of meaning" (Hochman, 1985, p. 70). Moreover, mindful of feminist scholarship which has emphasized how exclusionary language and the "symbolic annihilation" (Tuchman, 1978) of female characters contributes to gender inequality, we argue that the "backgrounding" and/or "unnaming" of characters with disabilities may function in similar ways and, in the context of children's literature, be especially fateful inasmuch as characters in this genre are more likely than in others to "serve as ideological (or rather educational) vehicles" (Nikolajeva, 2002, p. x). One might consider, in this context, the controversy that has encircled the 1970 Newbery winner, Sounder (Armstrong, 1969), which chronicles the struggles of an impoverished African American family but, in doing so, only names their one-eyed dog. As Wilkin (2009, p. 85) observes, while its author's intention may have been to "present this family as a generic group representing many...for a community seeking representation in the literature, personal humanity was at stake."

In addition, given that books that won Newbery awards during the time period investigated by Leininger et al. (2010) included biographies and hagiographies, nonfictional accounts of historic events and purely fictional works that chronicled the adventures of an admixture of human and anthropomorphized characters or characters that dwelt in other-worldly climes or who possessed supernatural powers, it is regrettable that their description of their method does not specify whether their analysis included or excluded nonhuman characters and those who acted in nonmimetic modes. However, this lack of specificity is not anomalous among research which has investigated representations of disability within children's literature. For example, while Ayala's (1999, p. 107) oft-cited article on this topic reports that "[t]he criteria for book selection was limited to picture books and intermediate readers written between 1974 and 1996 which contained a primary character who had a handicapping condition," the term "handicapping condition" is left undefined, along with the criteria that were employed to 
“Other" Characters

distinguish a "primary character" from a "secondary" one.

\section{Investigating Representations of “Disability” in Children's Literature}

Any earnest researcher who seeks to investigate how "disability" is represented in children's literature will confront an array of challenges that begin with task of defining this extraordinarily pliable term. As Mairs (1996, p. 12) observes, "one of the underlying problems with a comprehensive term like 'disability'...is that there has never been any universal agreement about who belongs in the company and who does not, or even what to call the presumed members." While the task of coding "disabled" characters may be eased by the employment of medicalized frameworks that reference such authoritative tomes as the IDEA (Irwin \& Moeller, 2010) or DSM (Weaver, 2008), doing so may result in a premature hardening of the categories that are conventionally understood to constitute "disability." For example, while various analyses have noted that disability within children's picture books is commonly depicted as an immutable condition, with the orthopedically-challenged and visually-impaired cast as paradigmatic “disabled persons” (e.g., Blaska \& Lynch, 1998; Prater, 1999), these findings may at least partially derive from the ways in which "disability" has been operationalized. For example, if the "disabled body" and "prosthetic body" are conflated, with various assistive devices (e.g., glasses, crutches, wheelchairs) construed as the most reliable signifiers of "disability," it is predictable enough that certain types of disability will figure more prominently than others.

Berube (2006, p. viii) observes that the topic of "disability (in its mutability, its potential invisibility, its potential relation to temporality, and its sheer variety) is a particularly elusive element to introduce into any conjunctural analysis, not because it is so distinct from sexuality, class, race, gender, and age but because it is always so complexly intertwined with everything else." Recognizing that bodies may be tagged as "disabled," "abnormal," "handicapped," 
Nelson and Nelson

"freakish" or "deformed" in certain contexts and not others (e.g., Garland-Thomson, 2009; Schweik, 2009), it would seem essential to acknowledge this indeterminacy. Nevertheless, this may be discouraged within analyses that accord primary to the placement of literary characters within such disability "categories" or types. For example, Solis (2007, p. 61) commends the use of a typology which distinguishes between disabilities that are (a) physical ("as in bodily functions distinguished from the mind or intellect and not necessarily characterized by relapsing, progressing, or chronic illness [e.g., paraplegia and missing limbs]”); (b) chronic ("conditions marked by long duration, frequent recurrence, relapsing or remitting, and slow-progressing seriousness [e.g., epilepsy and diabetes]"); (c) sensory ("relating to the senses or sensations, such as transmitting impulses from sense organs to nerve centers [e.g., visual impairment and hearing impairment]"); and (d) cognitive ("characterized by conscious mental or intellectual activity involving awareness, perception, remembering, thinking, reasoning, and judgment [e.g., learning disabilities and retardation]"). However, as Nikolajeva (2002, pp. 9, 220) cautions, if literary characters "seldom have bladders or intestines," their physical and mental ailments need "not necessarily follow the prescribed behavioristic patterns" of specific conditions.

Given that the descriptions that appear within Newbery Medal-winning books are rarely clinical, with diagnostic labels (e.g., aphasia, poliomyelitis) far less common than derogatory lay terms (e.g., "moron," "cripple"), one may anticipate that the characters they describe will always be uneasily positioned within biomedical typologies. In illustration, one might consider "Aggie," the "mistreated, undernourished and retarded girl, the youngest girl of a shiftless, vicious father and a mother who had been beaten down by the cruelties of her life," in the 1967 Newbery winning Up a Road Slowly (Hunt, 1966). While "Aggie" is described as "a retard” by "direct definition" (Rimmon-Kenan, 1983, p. 59), the text that surrounds this label frustrates sure pronouncements on whether she possesses a "congenital defect," a "cognitive learning disorder," 
a "sensory impairment" or suffers most fundamentally from the ravages of poverty. Similarly, while Leininger et al. (2010, p. 585) identify the character of "Marybeth" in the 1983 winner as having a "learning impairment," her description within the text is actually more ambiguous. Thus, the character's sister is described as pondering "whether or not Maybeth was retarded as people claimed, or only shy, slow, and frightened" and as favouring the latter interpretation (Voigt, 1982, p. 5). One may also contemplate the utility of Solis' preferred typology in relation to the very first winner of the Newbery Medal - van Loon's (1921/1984) The Story of Mankind. Although the paratext of this book includes the boast that it has "charmed generations of readers of all ages with its warmth, simplicity, and wisdom" and "been translated into no fewer than eighteen languages," its contents make pellucid that "disability" is not easily reduced to medicalized strictures and, instead, must be considered as a construct that encodes particular ideologies and historical moments. Thus, this book forwards a sneering depiction of the Islamic prophet Muhammad as an "epileptic" "lunatic" who "suffered from spells of unconsciousness when he dreamed strange dreams and heard the voice of the angel Gabriel, whose words were afterward written down in a book called the Koran" (van Loon, 1921/1984, p. 139). In like fashion, van Loon's (1921/1984, p. 461) emphatic insistence that "A Zulu in a frock coat is still a Zulu. A dog trained to ride a bicycle and smoke a pipe is still a dog" would seem to invite attention to how racial essentialism may be implicated in the production of "disability" within children's literature, with non-white "racial" identity equated with various forms of impairment. Indeed, the justification that van Loon (1921/1984, p. 449) offers for what his "story of mankind" excludes would, in itself, seem inordinately telling: "No race ever played a more picturesque role in history than the Mongolians, and no race, from the point of view of achievement or intelligent progress, was of less value to the rest of mankind."

The sentiments that van Loon expresses are hardly anomalous with Newbery-winning 
texts. For example, the villain in the 1927 award-winner is described as "a scrub of a degenerate halfbreed" who is " not fit to be classed among humans" (James, 1926/1962, pp. 208, 237); the titular character of the 1936 winner concludes, with "[s] omething of sadness" that "Indians" are a "doomed race" (Brink, 1935, pp. 30); and, in the 1960 winner, the leader of a group of Rotarians is only moved to act charitably towards a character who is "too dumb, too stupid, too much of an ox, a mule, a buffalo, to be like anyone else" (Krumgold, 1959, pp. 161, 96-97) after learning that his country sends "billions of dollars all over the world trying to civilize the Umbangis and natives like that!” In consequence, while a strict application of Solis' schema might favour coding the prophet Mohammed as exemplary of one "type"of disability and position "negroes," "Mongolians," "half-breeds," "Indians" and "Umbangis" as illustrative of others, it would seem preferable to employ a definition of "disability" which acknowledges both its protean nature and that "[h]ow a society defines disability and whom it recognizes as disabled also reveal a great deal about that society's attitudes and expectations concerning the body, what it stigmatizes and what it considers 'normal' in physical appearance and performance, what activities it takes to be necessary and/or valuable and for whom, and its assumptions about gender, age, race, caste and class" (Wendell, 1996, p. 32). In addition, rather than assume that representations of disability that appear within early Newbery-Medal winning books are less potent and/or worthy of consideration than those which have appeared more recently, we allow for the possibility that the opposite may also be true, with texts accruing particular lustre when endowed with "classic" status. For example, while it must remain speculative, the identification of van Loon's book as the "premier Newbury award winner" may constitute a "god trick" (Haraway, 1991, p. 189) that imbues its "truth" claims with especial authority and results in a privileging of its discursive regimes. 
“Other" Characters

\section{Method}

Our content analysis of Newbery medal-winning books, 1922-2012 employs the social model of disability that is expressed within the United Nations' Convention on the Rights of Persons with Disabilities (United Nations, 2007). This definition implicitly acknowledges that not all "impairments" result in "disability" and "explicitly recognizes the possibility that the primary causes of a disabled person's inability to do certain things may be social; they may be lack of opportunities, lack of accessibility, lack of services, poverty or discrimination, and they often are" (Wendell, 1996, p. 13). Moreover, inasmuch as the preamble to the Convention describes disability as an "evolving concept," we were encouraged to take heed of the 2000 Supreme Court of Canada's decision in Quebec v. Boisbriand 2000 SCC 27, [2000] 1 S.C.R. 665 and its ruling that "disability" may include "non-traditional disabilities" such as alcoholism, drug addiction and obesity.

To identify characters with an "impairment," both authors twice read all of the books that were the recipients of the Newbery medal from 1922-2012 and evaluated each character with reference to the United Nations' (2007) definition of an "impairment” (i.e., “Any loss or abnormality of psychological, physiological, or anatomical structure or function"). The broadness of this term allowed for the inclusion of any character, named or unnamed, who was described as having at least one visible and/or invisible impairment. Recognizing that children's literature has long included anthropomorphized characters, especially in the telling of morality tales, we did not set aside characters such as "Despereaux," the "sickly," "ridiculously small" mouse with "obscenely large ears" who is the titular character of the 2004 Newbery winningbook (DiCamillo, 2003, pp. 16-17). However, inasmuch as the term "impairment" implies a departure or deviation from "normal" functioning or structure, we excluded suprahuman characters who were described as belonging to a species that allowed its members to turn into a 
creature that was "something like a horse but at the same time completely unlike a horse" with "wings made of rainbows, of light upon water, of poetry" at its shoulders ("Mrs. Whatsit," in $A$ Wrinkle in Time [L'Engle, 1962, p. 61]).

We next evaluated whether each character with an impairment was depicted as "disabled" (i.e., "hindered from full and effective participation in society on an equal basis with others"). Conscious of Thurer's (1980, p. 14) report that within children's picture books, "virtue is rewarded with physical grace, so that the ugly duckling turns into a swan; the frog, a king; and the Beast, a prince," we also recorded whether or not by the story's end a character's impairment had changed in any significant way (e.g., through a "medical miracle" [Riley, 2005]) and, if so, whether these changes were suggestive of retributive justice. In this context only, we included characters who were initially presented as having an impairment but later revealed to be, for example, an otherworldly creature who possessed suprahuman powers.

Our coding of the "race" of characters with an impairment signals agreement with Streeter's (2009, pp. viii-viii) assertion that while "[d]rawing attention to race portrayals of people of color" is controversial, "[w]e live in a world where race matters" and that "[e]xcluding images of racial/cultural differences in literature doesn't make it inclusive but makes it insensitive at best and harmful at worst." However, while Nisse's (2008) report of growing diversity within Newbery-winning novels seems based, in part, on his readiness to identify Despereaux the mouse as being of an "ethnicity" that is "non-white, non-Black, non-Asian, nonHispanic, non-Polynesian and non-Native American," we felt that the setting of a story (in this case, France) was an unreliable indicator of the "ethnicity"/"race" of its anthropomorphized characters. Thus, while the story of the pigeon Gay Neck (Mukerji, 1927) is set in India, we thought it unwise to code its titular character as "East Indian" without a textual referent that would support our doing so and, instead, elected to restrict our coding of "race" to human 
characters. At the same time, inasmuch as all of the anthropomorphized animals within these novels were made clearly identifiable as "male" or "female" through the use of genderidentifying names, pronouns and, frequently, an explicit announcement of their kinship roles (e.g., mother, brother, daughter), we did include these characters in our coding of gender.

Following these initial divisions, the contents of each category were further coded into a modified version of Klapp's (1962) schema of heroes, villains and fools. In his work, Klapp suggested that this schema represents three dimensions of human behaviour. That is, heroes are praised and set up as role models, whereas villains and fools are negative models, with the former representing evil to be feared and/or hated and the latter representing figures of absurdity inviting ridicule. Klapp's categories seemed useful for they readily accommodate many of the stereotypes identified by Biklen and Bogdan (1977), offer a set of personas that are at once dramatic and hyperbolic and invoke well-established cultural archetypes of the good, the bad and the silly. However, recognizing that Klapp's set of personas is not exhaustive and that disabled persons may be represented in ways that emphasize their "rolelessness" (i.e.., as "atmosphere or curio"; "pitiable and pathetic," "a burden" or "incapable of participating fully in everyday life" [Biklen \& Bogden 1977]), we anticipated this possibility in our adoption of a fourth category: Other. The contents of each category were analyzed in terms of their constituent parts and compared across gender and "racial" categories. In all cases, inter-rater agreement was high (over 90\%) and disagreements easily resolved.

\section{Findings}

We identified 273 characters with at least one impairment who were named $(\mathrm{N}=224$ [82.1\%]) or unnamed (N=49 [17.9\%]) within Newbery Medal winning books, 1922-2012. The majority of these characters were male (69.6\%). Both male and female (human) characters with an 
Nelson and Nelson

impairment were overwhelmingly depicted as white $(70.2 \%$ of male characters $[\mathrm{N}=171]$ and $77.7 \%$ of female characters $[\mathrm{N}=94])$. Almost four out of five $(77.8 \%)$ non-white characters ( $\mathrm{N}=72)$ were depicted as either "Asian" (29.2\%), "Black" (27.8\%) or Hispanic (20.8\%). Female characters were more likely to be unnamed than male characters (20.2\% vs $16.8 \%)$; non-white characters were more likely to be unnamed than white characters (26.4\% vs $15.5 \%)$; and nonwhite females characters were more like to be unnamed than their male counterparts (42.9\% and $19.6 \%$, respectively).

Regardless of "race," unnamed female characters with an impairment $(\mathrm{N}=19)$, as well as those who were identifiable only through their relationship to another (i.e., a character who was solely described as "Frederick's wife" or "Eric's mother"), were overwhelmingly depicted as Other and represented in fleeting fashion as either a pitiable figure or a "curio." As examples of the former, the 1929 winner briefly singles out an unnamed "woman with a back bent to a curve" (Kelly, 1928, p. 29) in describing a group of beggars; in the 2005 winner, a unnamed "little girl in a blue dress" (Kadohata, 2004, p. 237) appears only long enough for her to be identified as having cancer and situated as a figure of pathos. As examples of the latter: the 2012 winner offers up, in the form of two very brief digressions: "the story of the Slater 'girl' who was captured by Indians in the 1830s, knocked unconscious with a war club and scalped with a knife, but still managed to abscond with her life and survive hairlessly to live to a ripe old age beneath a wig made of curly hamster hair" as well as a report on the marriage of Fred, an auxiliary character, to an unnamed "circus attraction who when she was a girl had a piece of white picket fence driven through her upper torso during the great Johnstown Flood of 1889" (Gantos, 2011, pp. 30-31).

Depictions of unnamed male characters with an impairment $(\mathrm{N}=30)$ were more diverse although not always more positive. For example, the protagonist of The Matchlock Gun 
(Edmonds, 1941, p. 62) notes proudly that his grandmother and her slaves had discovered an unnamed "Indian crippled and had killed him"; in his account, the murdered man is situated as a “culturally legitimate victim" (Weis and Borges, 1973). While unnamed men were sometimes cast as "pitiable" and as a "curio," they were more often described as either heroes and villains. Most notable among the "hero" category were legions of patriotic soldiers who "cheerfully gave legs and arms and lives" for their country [van Loon 1922/1984, p. 352], or, when called into a makeshift amputation tent, announced to their comrades "almost gaily, 'Next time you see me, my dancin' days will be over forever'” (Keith, 1957, pp. 70-71) or, after wartime time injuries resulted in the amputation of both legs, went "vaulting along the sidewalk" in a wheelchair and, in doing so, demonstrated both "tremendous upper-body strength" and "the guts it took to haul yourself all over town this way" (Perkins, 2005, pp. 289-291). Unnamed male characters who were cast as "villains" included kidnappers with "pock marks," "warts," and "scars" (Fox, 1973, p. 11) and murderers who were described as "a lunatic" or "half-crazy" (van Loon, 1921/1984, pp. 424, 455). Nevertheless, unnamed racialized male characters were, like women, most often depicted as "pitiable and pathetic" or simply as "curios."

In contrast to their female counterparts, however, it was extremely rare that a male character of any "race" would only be "named" through their relationship to another. This difference would seem attributable to the prominence of child protagonists within Newberywinning stories, their more frequent description as "motherless" than "fatherless," and the far greater likelihood that the announcement of a mother's - but not a father's - impairment would be quickly coupled with a report of her death. Thus, while fathers with impairments also died within these stories (e.g., Armstrong, 1969, pp. 91-94), their textual “diagnosis” was followed by a period of survivorship that allowed for their establishment in other than "shadow" roles. For example, although both of "Eric's" parents die during his childhood in Thimble Summer 
(Enright, 1938), his mother's death is reported in a sentence fragment while his father's death is described in detail over the course of several pages. In like fashion, while fathers could be depicted as severely depressed (Byars, 1969), alcoholic (Hesse, 1997) or "shell shocked" (Sorsensen, 1956), it was mothers with impairments who were most likely to be positioned "elsewhere": "crazy sick" to an extent that required hospitalization (Voigt, 1982, p. 12) or having an unusual "kind of illness... [that] makes her live in Italy" (Sawyer, 1936, p. 14). However, regardless of whether the textual banishment of mothers with impairments occurred through death or relocation, their delimited depiction made these women essentially "roleless": they were only identifiable through their relationship to others and/or as the embodiment of a specific impairment.

This type of dehumanizing characterization also occurred in relation to named characters. For example, while the 1947 Newbery winner records that "Old Simon, a crippled colored man had brought ice for everybody in his two-mule wagon and was carrying it in" (Lenski, 1946, p. 123), the character disappears after this introduction. Similarly, readers of the 1992 winner learn only that the impairments of "Grandma Preston" make her "real feeble" and that her care commands the hiring of nurses and consumes "every spare cent" that her family possesses (Naylor, 1991, p. 39). While named characters with impairments who were described as elderly were likely to occupy "satellite" or "backdrop" roles (Nikolajeva, 2002, p. 112) and to be cast as Other, regardless of their gender, this was especially true of racialized characters. However, when positioned in less peripheral roles, the depiction of these characters was more notably gendered than racialized. For example, regardless of their "race," elderly named men with an impairment were most often depicted as heroic and as "broken but unbowed." In illustration, the 2002 winner describes "Crane-man,” an elderly Asian man with a deformed leg, in ways that emphasize his agency: "Small and slight and who knew how old, Crane-man still moved his 
upper body with the ease of a young man; many were the times that Tree-ear forgot completely about the useless leg" (Park, 2001, pp. 7, 22). The protagonist of the 1965 winner reveres the "crippled" "famous bullfight critic" Alfonso Castillo as "a giant, something more than a man and a little less than a god" (Wojciechowsa 1964/1981, p. 135). While the 1944 winner early describes "Grandshire Silbee," as "confined mostly to his chair" due to wounds he sustained in battle forty years earlier, he is depicted as resuming his role as a military commander at the outbreak of war and, with "his old gun across his knees," being transported in his chaise to lead a battalion (Forbes, 1943, pp. 116, 293).

In comparison to their male counterparts, elderly women with an impairment were more likely to be presented as "disabled" by their impairment and, when depicted as "heroic," to appear as veritable personifications of such stereotypically "feminine" attributes as nurturance. For example, "May" is lavishly praised by the protagonist of the 1993 winner for being "a big barrel of nothing but love" (Rylant, 1992, p. 15) and, in the 2011 winner, the protagonist portrays "Miss Sadie" as ennobled by her readiness to subordinate her interests to those of her son: "If she reveals herself as his mother, she will bring shame on him....So what does she do?....She loves....And she bears the weight of that love" (Vanderpool, 2010, pp. 332-333). Equally suggestive of gendered stereotypes, "villainous" elderly women with impairments were most commonly depicted as irascible "old hags" while "eccentric" "old maids" - "spinsters" or otherwise uncoupled women - were prominent among "fools." Thus, "Aunt Best" within the 1942 winner would surely seem ironically named for she is described as being a "horrifyingly ugly, cross old woman with two old-headed canes" who hurls nasty barbs "through her whiskers and toothless gums" (Forbes, 1943, p. 84).

This gendering of disability also occurred in relation to non-elderly characters. For example, it is noteworthy that the "heroism of" females was often once-removed or "heroism-by- 
Nelson and Nelson

proxy" with a "frail," "deformed" or otherwise impaired female acting as the "muse" of another, most often an able-bodied male, and inspiring courageous acts and noble deeds. For example, the 1952 winning “biography” Amos Fortune describes its titular character as being sustained through multiple hardships (which include, but are not limited to, his enslavement and forced relocation from Africa to America), by the memory of his twelve year-old sister, the princess Ath-mun, who was born with a "useless" and "deformed leg." In this fictionalized rendering of Fortune's life, Ath-mun plays a catalytic role in Fortune's achievement of freedom for himself and a series of women who, because of their impairments, remind him of his sister: "It was Athmun who had been the fount of freedom to those others, Amos thought, as he reached back into memory for the beloved sister; he had acted for her and so he would account to her when they met together at the Jordan” (Yates, 1951, pp. 168-169). Similarly, the 1962 Newbery winning novel chronicles how "Daniel's" desire to help his "hopelessly fragile" and tormented sister motivates his commission of various heroic acts (Speare, 1961). Female characters with an impairment were also posthumously repositioned in the role of "muse." For example, after Aggie's death prompts the protagonist of Up a Road Slowly (Hunt, 1965) to feel guilty for her cruelty towards her schoolmate, her uncle chides her: "Now, why should you feel guilty....? Hadn't you rather thank Heaven that she has escaped what life had to offer her? And isn't it a blessing that society escaped a multiplication of her kind?" (Hunt, 1965, pp. 65-66). Nevertheless, he also offers up praise, telling her: "your compassion as you grow into womanhood may well become immortality for the girl you call 'Aggie'” (Hunt, 1965, p. 67). A second common representation of "heroic" females with an impairment was as the quintessence of "femininity" and as "non-disabled" in any significant way. For example, the 1959 winner's description of the tellingly-named "Mercy," a young "lame" woman may be considered prototypical. Thus, when a minister's prayer requests a blessing for “our sister in her 
weakness and affliction," "Kit" the protagonist bristles, "Heavens, was he talking about Mercy?" and silently fumes that "Mercy certainly did not consider herself afflicted.... Mercy was the pivot about whom the whole household moved. She coaxed her father out of his bitter moods, upheld her timorous and anxious mother, [and] gently restrained her rebellious sister" (Speare, 1958, pp. 52-53). Later, while observing Mercy teaching young children, Kit "marvels" at the "ease and gentleness with which Mercy controlled her charges, her warm sweet voice never raised, her lovely composure never ruffled" (pp. 70-71). After "John," the man that Mercy has loved silently from afar, experiences an injury that results in his impairment and, on that basis, is rejected by his fiancé, Mercy and John happily wed. However, this casting of women with impairments as apostles of ideal-typical femininity was especially marked in representations of Asian women with impairments. Thus, the 1933 winner explicitly suggests that, for its focalizing character, any impairment that is caused by conformity to a cultural ideal of femininity is far less "disabling" than defiance of the ideal: "Everyone agreed that it was better to stand the agony of foot binding than the stigma of possessing large feet. And even though deformed feet permitted a woman to work only around the house, they were important in getting a husband" (Lewis, 1932, pp. 42-43).

The gendered meaning of disability was most markedly suggested by the disparate work statuses of male and female characters with an impairment. The former were almost invariably depicted with reference to a work-related status, whether ascribed (e.g., a king [de Trevino, 1965, p. 93]) or achieved (e.g., a carpenter [Hawes, 1923, p. 109]); or reputable (e.g., a horseboy [Henry, 1948, p. 61]) or disreputable (e.g., a horse thief [Armer, 1931]). This was not true of female characters. While the 1997 winner (Konigsburg, 1996, pp. 68-71) notes that "Mrs. Olinski" is both a "paraplegic" and an engaging elementary school teacher and the 1951 winner describes the enslaved "Lydia" who is "lame" as a "sewing woman" (Forbes, 1951, pp. 74-75), females with impairments were rarely described with reference to a work role or presented as 
Nelson and Nelson

capable of work. Thus, the 2004 winner reports that as a result of being "almost deaf," "a bit slow-witted," obese and "the tiniest bit lazy," one was "hard-pressed to find a job that Miggery Sow could effectively perform. In quick succession, Mig failed as a lady in waiting...a seamstress...and as a chambermaid" (DiCamillo, 2003, pp. 152-153). While the elderly and arthritic "Miss Volkers" in the 2012 winner is both a trained nurse and the town's medical examiner (Gantos, 2011, pp. 29, 306), she is portrayed as incompetent: When tasked with examining the cadavers of seven elderly women with impairments, Miss Volkers fails to discern that each has been poisoned (by a man whom she has spurned as a suitor). In contrast, while "Richard" in the 2010 winner, is noted to "limp a little" "because his right leg is shorter than his left one," he is also described as a "tall, blond" successful lawyer who is called "Mr. Perfect" by his girlfriend, the protagonist's mother, "because of how he looks and how he knows everything" (Stead, 2009, p. 4). Similarly, if "Doctor Sikes" in the 1979 winner "limps" into a room "on crooked legs" (Raskin, 1978, pp. 15-16), his impairment invokes no further commentary within the story. In like fashion, the animal fantasy Mrs. Frisby and the Rats from NIMH (O'Brian, 1971, pp. 79-80, 143) portrays the rat Nicodermus, who is missing an eye and has a scarred face, as the heroic leader of a resistance movement.

Although only one in ten $(10.3 \% ; \mathrm{N}=28)$ characters with an impairment was described as transformed by a "medical miracle" or other event that either eradicated or greatly ameliorated their impairment, these events were most likely to impact white male characters $(84.6 \%)$. For example, while "Chris" is initially introduced in the 1979 winner as the "poor crippled boy whose smile could break your heart" (Raskin, 1978, pp. 15-16), his unspecified "inherited disease" is described as improving markedly after his use of a "recently discovered" medication that steadies his limbs and controls his speech: he becomes a university professor of ornithology, marries a woman who is also a university professor and, while on a research trip to South 
America, discovers a "new subspecies" of parrot that is subsequently "named after him" (Raskin, 1978, p. 183). More frequently, however, these reversals of fortune favoured male characters with impairments that were exogamous rather than endogamous in origin and who demonstrated stoicism and courage in its aftermath. Thus, after a foe's treachery results in severe injury to "Johnny Tremaine's" hand, Johnny valiantly assists the Yankees in their fight against the British; at the end of the novel, he learns from a physician that surgery can restore his hand to point where it will be "good enough to hold...[a] gun" and immediately tells the doctor to proceed, emphasizing "I've got the courage"(Forbes, 1943, p. 291). The 1924 winner records that due to a young man's forbearance in the aftermath of a magical spell, "the boy regained his sight and the mother became as she had been, tall and straight and beautiful and kind" (Finger, 1925, p. 134). In the 1999 winner (Sacher, 1998, p. 7), a wrongfully imprisoned boy, who "weighs three times as much" as the others in his class, is both exonerated and lean by the story's end. Male characters who ostensibly possessed impairments could also be repositioned, by a story's end, as "superheroes" with extraordinary powers. Thus, the "Laughing Man" in the 2009 winner is revealed to have come from the future to save his (female) friend's life (Stead, 2009).

As the result of such gendered depictions of disability, it should not be surprising that female characters were less likely than their male counterparts to be depicted in the agentic roles of "heroes" and "villains" and more likely to be cast as Other (Table 1). Among male characters with impairments, the casting of non-white characters as Other was also notable: while a third of white male characters were presented in this way, this was true of half of those who were described as Hispanic and just over three-quarters (76.9\%) of those who were described as "Black." Among female characters with impairments, those who were depicted as white or nonwhite were equally likely to be Othered (71.2 versus $71.4 \%$, respectively). 
Table 1: Personas by Gender

\begin{tabular}{lrrrrrr}
\hline & \multicolumn{2}{c}{ Males } & \multicolumn{2}{c}{ Females } & & \\
& $\mathrm{N}$ & $(\%)$ & $\mathrm{N}$ & $(\%)$ & $\mathrm{N}$ & $(\%)$ \\
Heroes & 52 & $(29.1)$ & 11 & $(11.7)$ & 63 & $(23.1)$ \\
Villains & 48 & $(26.8)$ & 7 & $(7.4)$ & 55 & $(20.1)$ \\
Fools & 13 & $(7.3)$ & 9 & $(9.6)$ & 22 & $(8.1)$ \\
Other & 66 & $(36.9)$ & 67 & $(71.3)$ & 133 & $(48.7)$ \\
$\mathrm{N}$ & 179 & $(100.1)$ & 94 & $(100.0)$ & 273 & $(100.0)$ \\
\hline
\end{tabular}

\section{Conclusion}

In Mellon's (1989, p. 47) impressionistic account of how “exceptionality” in children was portrayed within "juvenile books about disability," she lamented that "stereotypes of the physically disabled child" infused these books, with the two most common being the "poor little thing" and "brave little soul." A decade later, Ayala's (1999, p. 107) incorporation of these phrases into the title of his article would foreshadow the results of his analysis of 59 picture books and intermediate readers with a "primary character who had a handicapping condition"; he reported that the majority (63\%) depicted "the protagonist as a hero, typified as the 'brave little soul," with $10 \%$ characterizing the individual with a disability as a "victim or outcast" and simply one book portraying the main character as "somewhat villainous" (Ayala, 1999, p. 111). While our investigation of Newbery medal-winning books finds greater variability in representations of characters with impairments, it must be emphasized that our sample was not restricted to juvenile books "about disability" nor were we solely concerned with how a "primary character who had a handicapping condition" was depicted. Rather, we tended to the depiction of any character, whether primary, secondary or "background," who was presented as having an impairment. Our results indicate that almost one in two of these characters were Othered and presented as "roleless." This was especially true of female characters, with more than seven out of ten presented in this way. However, as Garland-Thomson (2002, p. 6) has observed, "Western thought has long conflated femaleness and disability, understanding both as defective departures 
“Other" Characters

from a valued standard."

The characterization of females with impairments would seem to illustrate the enduring utility of Fine \& Asch's (1981) concept of “sexism without the pedestal.” In coining this concept, Fine \& Asch (1981, pp. 233-234) directed attention to the systemic "rolelessness" that is imposed upon "disabled women" and emphasized that when compared to both "disabled men" and "nondisabled women," differently-abled women experience "a distinct disadvantage" with "[f]ewer socially sanctioned roles viewed ... [as] appropriate... and relevant disabled role models ... virtually invisible." While females characters with impairments were not invisible within the imaginary worlds created by Newbery medal-winning books from 1922-2012, it is evident that these books contained a greater number of male than female characters with impairments and that their portrayal was not interchangeable. Rather, the crafting of these characters generally paid homage to traditional gender roles, images and symbols and, perhaps most notably, reiterated an active-masculine/passive-feminine dichotomization. In consequence, if "masculinity" is "precarious" (Vandella et al., 2008, p. 1337) while the establishment of "authentic femininity" "rarely involves tests or proof of action, or confrontations with dangerous foes" (Gilmore, 1990, p. 12), the "disabling" of female characters with an impairment and "abling" of their male counterparts may emerge as by-products of the gendering of literary characters, with females more likely to be portrayed as fungible than either heroic or villainous.

Although characters within Newbery award-winning books between 1922 and 2012 were rarely described as possessing the Aharmonic @ bodies that were equated with divinity in medieval times and extolled in the Renaissance questing after a perfectly proportioned figure, the contents of these books suggest that certain bodies are more likely to be "disabled" than others. With the notable exception of books in which the majority of characters are depicted as non- 
white, racialized characters with impairments most often appear as unnamed background characters and in ways that accord with the stereotype of a villain as a "dark-haired figure, often with some visible disfigurement and excessive facial hair" (Nikolajeva, 2002, p. 115). Moreover, while award-winning books of the past decade are more inclusive in their "racial" composition than their counterparts in earlier decades, it was the 1933 award-winning Yu Fu of the Upper Yangtze (Lewis, 1932) that seemed to most forcefully encourage its "implied readers" - white, upper- and middle-class children (Nikolajeva, 2002, p. 204) - to consider "disability" critically and contemplate its nexus with ethnocentrism and xenophobia. Thus, when Yung Fu expresses his perception that white "foreigners" have hands, feet and noses that are "twice the size of a normal beings" and skin that "resembles a poorly plucked fowl," his comments could suggest the value of approaching "disability" with an anthropological gaze that questions everything and regards ordinary classification systems as extraordinary. However, during the totality of the period under scrutiny, disability was more often presented as a condition that allowed males to demonstrate efficacy and caused females to disappear. 
“Other" Characters

\section{References}

American Library Association (2014). Terms and criteria: John Newbery medal. Retrieved from http://www.ala.org/ala/mgrps/divs/alsc/awardsgrants/bookmedia/newberymedal/newberyt erms/newberyterms.cfm.

Armstrong, W.H. (1969). Sounder. Santa Barbara, CA: Cornerstone Books.

Ayala, E.C. (1999). "Poor little things" and "brave little souls": The portrayal of individuals with disabilities in children's literature. Literacy Research and Instruction, 39(1), 103-117.

Beckett, A., Ellison, N., Barrett, S. \& Shah, S. (2010). “Away with the fairies?" Disability within primary-age children's literature. Disability \& Society, 25(3), 373-386.

Berube, M. (2006). Foreword. In R. McRuer, Crip theory: Cultural signs of queerness and Disability (pp. vii-xi). New York: New York University Press.

Biklen, D. \& Bogdan, R. (1977). Media portrayals of disabled people: A study in stereotypes." Interracial Books for Children Bulletin, 8, 4-9.

Blaska, J.K. \& Lynch, E.C. (1998). Is everyone included? Using children's literature to facilitate the understanding of disabilities. Young Children, 53(3), 36-38.

Boster, M.A. (2005). Gender equity of traditional and non-traditional career roles in Newbery award-winning and honour books (Doctoral dissertation), Liberty University.

Bones G.N. (2010). The six pillars of character in $21^{\text {st }}$ century Newbery award books (Doctoral dissertation), Liberty University.

Brink, C.R. (1935). Caddie Woodlawn. New York: Macmillan.

Byars, B. (1970). Summer of the swans. New York: The Viking Press.

Chrisman, A.B. (1925). Shen of the sea. New York: E.P. Dutton \& Company, Inc.

Clark, R. (2007). From margin to margin? Females and minorities in Newbery and Caldecott medal-winning and honor books for children. International Journal of Sociology of the Family, 33(2), 263-283.

Cook, T.E. (1985) The Newbery award as political education: Children's literature \& cultural reproduction. Polity, 17(3), 421-445.

Cooper, S. (1976). The grey king. New York: Atheneum.

Creech, S. (1994). Walk two moons. New York: Harper/Collins.

de Trevino, E.B. (1966) I, Juan de Pareja. New York: Bell Books.

DiCamillo, K. (2003). The tale of Despereaux. Cambridge, MA: Candlewick Press. 
Nelson and Nelson

Dyches, T.T. \& Prater, M.A. (2005). Characterization of developmental disability in children's fiction. Education and Training in Developmental Disabilities, 40(3), 202-216.

Edmonds, W.D. (1941). The matchlock gun. New York: The Putnam \& Grosset Group.

Enright, E. (1938). Thimble summer. New York: Yearling.

Fine, M. \& Asch, A. (1981). Disabled women: Sexism without the pedestal. Journal of Sociology and Social Welfare, 8(2), 233-248.

Finger, C.J. (1924). Tales from silver lands. Garden City, New York: Doubleday \& Company, Inc.

Forbes, E. (1943). Johnny Tremain. Boston: Houghton Mifflin Company.

Gantos, J. (2011). Dead end in Norvelt. New York: Farrar Straus Giroux.

Garland-Thomson, R. (1996). Freakery. New York: New York University Press.

Garland-Thomson, R. (1997). Extraordinary Bodies. New York: Columbia University Press.

Garland-Thomson, R. (2002). Integrating disability, transforming feminist theory. NWSA

Journal, 14(3), 1-32.

Garland-Thomson R (2009). Staring. New York: Oxford University Press.

Gartner A \& Joe, T. (Eds.) (1987) Images of the disabled, disabling images. New York: Praeger.

Gilmore, D.D. (1990). Manhood in the making. New Haven, CT: Yale University Press.

Haraway, D. (1991). Simians, cyborgs and women. New York: Routledge.

Hawes, C.B. (1923). The dark frigate. New York: Little, Brown and Company.

Henry, M. (1948). King of the wind. New York: Rand McNally \& Company.

Hesse, K. (1997). Out of the dust. New York: Scholastic Press.

Hochman, B. (1985). Character in literature. Ithaca, NY: Cornell University Press.

Hunt, I. (1966). Up a road slowly. Chicago: Follett Publishing Company.

James, W. (1926/1962). Smoky the cow horse. New York: Charles Scribner's Sons.

Kadohata, C. (2004). Kira-kira. New York: Atheneum Books for Young Readers.

Keith, H. (1957) Rifles for Watie. New York: HarperCollins Publishers.

Kidd, K. (2007). Prizing children's literature. Children's Literature, 35, 166-190. 
Klapp, O. (1962). Heroes, villains and fools. Englewood Cliffs, NJ: Prentice-Hall.

Konigsburg, E.L. (1996). The view from Saturday. New York: Jean Karl Book/Atheneum Books for Young Readers.

Krumgold, J. (1959). Onion John. New York: Crowell.

Lathey, J. (2005). Challenges then and now: A survey of protagonists in Newbery award books, 1950s and 1990s. Children and Libraries, 3, 20-24.

Leininger M., Dyches,T.T., Prater, M.A. \& Heath, M.A. (2010). Newbery award winning books 1975-2009: How do they portray disabilities? Education and Training in Autism and Developmental Disabilities, 45, 583-596.

L’Engle, M. (1962) A wrinkle in time. New York: Farrar, Straus and Giroux.

Lenski, L. (1945). Strawberry girl. New York: Harper/Trophy.

Lewis, E.F. (1932). Young Fu of the Upper Yangtze. New York: Henry Holt and Company.

Lopez-Crowley, L.A. (2007). Representation and characterization of Mexican American characters in Newbery book medal winners, 1922-2006 (Doctoral dissertation), University of Denver.

Lowe, B. (2004). Eying the price: race relations in Newbery Award novels, 1922-2000 (Doctoral dissertation), University of Mississippi.

Mairs, N. (1996). Waist-high in the world. Boston: Beacon.

Mellon, C.A. (1989). Exceptionality in children's books: Combining apples and oranges. School Library Journal, 2, 46-47.

Moeller, R. \& Irwin, M. (2010) Seeing different: Portrayals of disability in young adult graphic novels. School Library Media Research. Retrieved from http://www.ala.org/aasl/aasl/ pubsandjournals/slmrb/slmrcontents/volume13/irwin moeller

Moeller, R. \& Irwin, M. (2012). Seeing the same: A follow-up study on the portrayals of disability in graphic novels read by young adults. School Library Research. Retrieved from http: www.ala.org/aasl/aasl/pubsandjournals/slmrb/slmrcontents/volume15/ irwinmoeller

Mukerji, D.G. (1927). Gay Neck. New York: E.P. Dutton \& Co., Inc.

Naylor, P.R. (1991). Shiloh. New York: Atheneum.

Nikolajeva, M. (2002). The rhetoric of character in children's literature. Lanham, Maryland: The Scarecrow Press, Inc. 
Nelson and Nelson

Nisse, A. (2008). Do you see what I see? Portrayals of diversity in Newbery-medal-winning children's literature (Masters Thesis), Brigham Young University.

O’Brien, R. (1971). Mrs. Frisby and the rats from NIMH. New York: Atheneum.

Park, L.S. (2001). A single shard. New York: Clarion Books.

Peck, R. (2000). A year down yonder. New York: Dial Books for Young Readers.

Perkins LR (2005) Criss Cross. New York: Greenwillow.

Prater, M.A. (1999). Characterization of mental retardation in children's and adolescent literature. Education and Training in Mental Retardation and Developmental Disabilties, 36(3), 418-431.

Raskin, E. (1978). The westing game. New York: Dutton Children's Books.

Riley, C.A. (2005). Disability and the media. Lebanon, NH: University Press of New England,

Rimmon-Kenan, S. (1983). Narrative fiction. London: Methuen.

Rylant, C. (1992). Missing May. New York: Orchard Books.

Sachar, L. (1998). Holes. New York: Dell-Laurel Leaf.

Sandell, R. \& Dodd, J. (2010). Activist practice. In R.Sandell, J. Dodd \& R. Garland-Thomson (Eds.), Representing disability (pp. 3-22). London: Routledge, Taylor \& Francis Group.

Sawyer, R. (1936). Roller skates. New York: The Viking Press.

Schweik, S. (2009). The ugly laws. New York: New York University Press.

Solis, S. (2007). Coloring outside the line: Problematizing disability representations in children's picture books (Doctoral dissertation), Columbia University.

Stead, R. (2009). When you reach me. New York: Wendy Lamb Books.

Streeter, E.L. (2009). Forward. In B.T. Wilkin, African and African American Images in Newbery Award Winning Titles (pp. vii-x). Lanham: The Scarecrow Press, Inc.

Taylor, M.D. (1976). Roll of thunder, hear my cry. New York: Puffin Books.

Thurer, S. (1980). Disability and monstrosity: A look at literary distortions of handicapping conditions. Rehabilitation Literature, 45(1-2), 12-15.

Tuchman, G. (1978). Making news. New York: Free Press.

United Nations. (2007). Convention on the Rights of Persons with Disabilities. Retrieved from www2.ohchr.org/english/law/disabilities-convention.htm. 
Vandello, J.A., Bosson, J.K., Cohen, D., Burnaford,R.M. \& Weaver, J.R. (2008). Precarious manhood. Journal of Personality and Social Psychology, 95(6), 1325-1339.

Vanderpool, C. (2010). Moon over manifest. New York: Random House.

van Loon, H.W. (1921/1984). The story of mankind. New York: Liverright Publishing Corporation.

Voigt. C. (1982). Dicey's song. New York: Atheneum.

Weaver, C. (2008). Characterization of autism spectrum disorders in children's picture books (Masters thesis), Brigham Young University.

Weis, K. \& Borges, S. (1973) Victimology and rape: The case of the legitimate victim. Issues in Criminology, 8, 71-115.

Wendell.S. (1996). The rejected body. New York: Routledge.

Wilkin, B.T. (2009). African and African American images in Newbery award winning titles. Lanham, MD: Scarecrow.

Wojciechowska, M. (1981). Shadow of a bull. New York: Atheneum.

Wollenziehn, J.L. (1996). Multicultural characters in Newbery award and honours books, 19831994: A content analysis. (Masters thesis), Central Missouri State University.

Yates, E. (1950). Amos Fortune, Free Man. New York: Dutton Children's Books. 